\section{Introduction: From the Exotic to the Autoexotic}

\author{
XIAOFAN AMY LI
}

XIAOFAN AMY LI is lecturer in comparative literature at the University of Kent, Canterbury. Her research focuses on comparisons between French and Chinese literature and culture, spanning topics such as intercultural encounters, the reception of Chinese antiquity in twentieth-century France, French ethnographic fiction, and Chinese poetics. She is working on her second monograph, a comparative study on play in literature and the arts.

\section{THIS CLUSTER OF ESSAYS STEMS FROM THE SPRING RECEPTION WORK-} SHOP ON AUTOEXOTICISM, WHICH WAS ORGANIZED BY THE OXFORD

Comparative Criticism and Translation Research Programme (OCCT) and the British Comparative Literature Association (BCLA) and took place on 19 March 2015 at the University of Oxford. Speakers at the workshop, also the contributors to this special feature, had been discussing the question of exoticism for the past few months. The topic of autoexoticism emerged through our discussions, and we felt the need to explore it because we were dissatisfied with the status quo of criticism on exoticism and intercultural practices. These essays are therefore both the result of our attempt to rethink exoticism and its discourses by articulating the autoexotic and an invitation to further explore and problematize the topic.

After Edward Said's Orientalism and much postcolonial theory, exoticism has become a somewhat tired theme leading to familiar discourses rehearsing the postcolonial critique of cultural and epistemological imperialism. To criticize exoticism seems to mean criticizing discourses and representations of the other from the viewpoint of the center, the more powerful (i.e., Western) culture, the original rather than the derived, the subject that constructs and objectifies an exotic other for its own consumption. These criticisms, all pertinent, are fundamentally a critique of power. The current perception of exoticism and those who have engaged with it is therefore generally tainted with negativity, exoticism carrying immediate connotations of unethical appropriation and superficial engagement with the other. This perception has contributed to the death of travel literature or its "veering obsolescence" (Apter 197) during the postwar years in Europe. Claude Lévi-Strauss's Tristes tropiques (1955) seems to have said the last word about European travelers' complicity with colonialist nostalgia in their search for exotic others, even with the best intentions of contributing to the anthropological project of studying humanity.

In our view, however, there is much more to exoticism than the question of power and ethics: exoticism was not only about appro-

(C) 2017 XIAOFAN AMY LI

PMLA 132.2 (2017), published by the Modern Language Association of America 
priation of the weak by the powerful, nor has it remained fundamentally unchanged since the colonial empires. After all, as early as the 1910s, Victor Segalen redefined exoticism as an "aesthetics of diversity," despite its problematic politics of power. The cultural, linguistic, psychological, and epistemological dynamics in exoticism encompass complex relations that are underexplored. We therefore think that a more fluid and relational notion of the exotic is needed, for undeniably the exotic depends heavily on its audience and their reception from a particular perspective. Something becomes exotic not because it is inherently so but because its audience and their perspective make it so. Despite the truism that the exotic is necessarily other, distant, and unfamiliar, this does not automatically explain why the exotic is always intertwined with desire. Something is exotic-or rather, exoticized-not only because it is different but also crucially because its difference appeals to its viewer and appears as new, interesting, attractive, exciting, eroticized, or even superior. This desireinfused characteristic of exoticism therefore makes the exotic a discourse, practice, or way of perceiving that is relational and emotional. More significant, what is relational and emotional is also what can be changed and negotiated. In fact, the contemporary revival of travel writing, especially in France since the 1992 movement of Pour une littérature voyageuse (Borer et al.), is one example that attests to the shifts in engaging with exoticism and renegotiation of cultural relations. With this issue as background, we would like to build on and renew debates about exoticism and rethink its related concepts and approaches.

This reconsideration of exoticism leads us to the notion of autoexoticism, which has, we believe, evolved from exoticism but differs in certain critical ways. Though still a relatively unfamiliar term, autoexoticism has cropped up in various cultural and literary studies in the past two decades. It was coined by Marta Savigliano in her 1995 Tango and the Political Economy of Passion, which argues that Argentinians' adoption of the tango as a symbol of their national identity was an autoexoticist internalization and reproduction of imperialist cultures' exoticized misrepresentation of the dance as typically Argentinian. Autoexoticism thus marks, in James Parakilas's words commenting on Spanish music, "the condition ... of being able to produce a marketable art only by exoticising oneself and one's culture" (139). Here we can observe the shift in agency in the production of the exotic, since exoticism is taken over by the exoticized other, reproduced and employed for the people of that other and to their own benefit. This change is also remarked in literary studies, especially with the appearance of Nathalie Schon's L'auto-exotisme dans les littératures des Antilles françaises (2003), where autoexoticism became an explicitly new discourse about literature with emphasis on its positively subversive aspect: "C'est en comprenant et en acceptant l'exotisme de l'Autre que l'auto-exotisme n'est plus une vision du monde imposée mais choisie" (18; "It is by understanding and accepting the exoticism of the other that autoexoticism becomes a chosen rather than imposed worldview" [my trans.]). The autoexotic thus asserts the regaining of agency and identity for writers such as Patrick Chamoiseau, Raphaël Confiant, and Maryse Condé, who have been so far seen in the shadow of the francophoniethat is, in deference to the supposed center of France and its colonial history. This assertion about self-fashioning is further confirmed in Joep Leerssen's argument about the "autoimage" as a version of autoexoticism that "look[s] for one's own identity in the unusual, the extraordinary, the exotic aspects of experience, to conflate the notions of one's distinctness and one's distinctiveness" (qtd. in Foster 3) -for instance, Irish writers' presentation of "their country as bizarre, ... even to 
themselves" (2). These scattered articulations of the autoexotic from various fields of criticism demonstrate that autoexoticism is, like exoticism, also a discourse and a way of audience response. But both its agent and audience are different from those of exoticism. In fact, the agent of exoticist construction and its recipient are reversed in autoexoticismfrom the weak to the powerful, the marginalized to the dominant. This self-reflexivity of autoexoticism thus reveals the fascinating and intriguing distance between the self and the self, for we realize that the self, like culture, is multiple and created through diverse discourses, and that self-perception originates from others' perception of oneself.

Existing scholarship as cited above has vaguely indicated a new way of thinking about cultural interactions and tensions in power hierarchies, the self-and-other relationship, intercultural practices in art, literature and thought, and comparative criticism. In this collection of essays, we feel the need to give more systematic clarification of autoexoticism and what is at stake in it by tying together various threads of thought and investigation. We start with the critique of certain facile assumptions about exoticismfor example, the view that exoticism always involves a dichotomy between self and other; that exoticization and translation necessarily depend on notions of cultural authenticity and textual originality; that interculturality is something that happens between cultures, thereby disregarding how it is inherent within a perceived cultural entity; or that there are multiple cultures (often with distinct differences) to exoticize about but not multiple natures, whereas the ontological turn in recent anthropology-as seen in Eduardo Viveiros de Castro's work on perspectivism in Amazonia (e.g., Métaphysiques cannibales ["Cannibal Metaphysics"]) and Philippe Descola's Par-delà nature et culture ("Beyond Nature and Culture")- has shown that certain peoples think that there are multiple natures. Our essays challenge these assumptions by exploring the notion of the autoexotic through the following questions.

What about reversing the gaze and seeing how the other perceives us? (This reversal has been theoretically championed for a long time but seldom realized in literary studies, which still focus on centers of cultural, economic, and linguistic power-Europe, the metropolis, the so-called major literaturesand position everything else concentrically.) How should we understand the exotic when it becomes an imagining of the self instead of the other? How should we make sense of the adoption by local or indigenous peoples of the exoticist discourses about them, which were invented by the supposedly dominating center, instead of seeing those discourses as a reinforcement of the center's power? If we are to retrieve the exotic from a commodifying language, what kind of language should we use to talk about encounters with the other, in literature, arts, and thought? What critical approach could have more ethical purchase and more epistemological depth, since conventionally exoticism means taking a superficial and consumerist attitude toward the other? Can the autoexotic be an ethical enterprise (in that it may challenge constructions of cultural entities, subjectivity, and identities by raising questions about our aesthetic, epistemological, and ontological boundaries)? Are there exoticist or foreignizing practices that can create interstitial spaces where the subject of experience or the object of discourse is neither self nor other but both simultaneously? If there are such practices, how may such spaces be constructed?

With these questions in mind, we explore in our essays three main strands of criticism, in literature, art, and translation studies, that articulate different facets of autoexoticism. The first strand concerns the recirculation of exoticist constructions back to the culture they originated from and indigenous self-fashioning through this 
double reflection for purposes of subversion, regaining agency, and questioning the idea of cultural authenticity. This strand is articulated by Valentina Gosetti, who discusses autoexoticism as a provincial literary ruse in nineteenth-century France; by Peter Hill, who discusses how Arab intellectuals talk back to French orientalist exoticism; and by Daniele Nunziata, who discusses autoexoticism in colonial women's writing on Cyprus in the British Empire. The second strand examines pseudo-identity as a kind of autoexoticism, which includes issues such as poetic cannibalization, derivation, pseudotranslation, self-translation, and foreignizing techniques and effects, which can lead to the mutual transformation of the original (the familiar) and the translated or the derived (the exotic). Contributions to this strand are made by Adriana X. Jacobs, who discusses Anna Herman and the Goldberg Variations; and by Kasia Szymanska, who examines Katerina Brac, a Polish poet invented by Christopher Reid, who supposedly translates her, and her English reflection. The third strand of inquiry theorizes an autoexoticist space created by writing and criticism that allows different literatures and cultures to interact and ruptures the boundaries of cultural entity and identity. In this strand are the consideration of cultural anthropophagy and self-fashioning, the creation of an intercultural space of literatures and cultures that is foreign to the home space of each supposedly native literature or culture that is involved; exoticizing effects that comparative thought and criticism produce by bringing together different comparanda into juxtaposition and interaction; cross-cultural comparisons where the self-other binary is liquidated because the perspective that constructs the exotic is the comparison rather than a particular culture or center of power. Essays in this strand are Xiaofan Amy Li's study of Antonin Artaud's autoexoticist articulations of culture, food, and epistemology; Minyan
Sun's analysis of the disrupture of ontological borders and self-externalization in Julio Cortázar's works; and Naomi Charlotte Fukuzawa's analysis of the formation of eclectic hybridity of Japanese modernity through the intercultural writings of Lafcadio Hearn and Natsume Sōseki. The special feature concludes with Matthew Reynolds's summarizing essay, which discusses the conjuring of a heuristic for an artwork by Jorge Méndez Blake that was generated from Spanish translations of James Joyce's Chamber Music and orientates toward the development of a literary criticism that exoticizes and disrupts the institutional academic language from within by being more creative and experimental.

By exploring these strands, we hope to show different aspects of the autoexotic while keeping its definition open for more debate. We recognize that there are, of course, many different ways of being autoexoticist, not all of which are about subversion or positive selfrepresentation. Nonetheless, we hope to have made a step toward the critical task of envisaging the possibility for an autoexoticism that challenges rather than reinforces the centrality of power, changes the boundaries of the endotic and exotic, exercises the flexibility to metamorphose between self and other, between the original and the derived, and allows the freedom of cultural self-fashioning instead of passively belonging to whatever culture one has been born into. Finally, we are glad to have gathered such a multilingual, multicultural, and interdisciplinary cluster of essays, which reflects the intercultural and comparative nature of the autoexotic texts and practices we explore.

\section{Works Cited}

Apter, Emily. Continental Drift: From National Characters to Virtual Subjects. U of Chicago P, 1999. 
Borer, Alain, et al. Pour une littérature voyageuse. Éditions Complexe, 1992.

Castro, Eduardo Viveiros de. Métaphysiques cannibales. PU de France, 2009.

Descola, Philippe. Par-delà nature et culture. Gallimard, 2005.

Foster, Robert Fitzroy. Words Alone: Yeats and His Inheritances. Oxford UP, 2011.

Lévi-Strauss, Claude. Tristes tropiques. Plon, 1955.
Parakilas, James. "How Spain Got a Soul." The Exotic in Western Music, edited by Jonathan Bellman, Northeastern UP, 1998, pp. 137-93.

Savigliano, Marta. Tango and the Political Economy of Passion. Westview Press, 1995.

Schon, Nathalie. L'auto-exotisme dans les littératures des Antilles françaises. Karthala, 2003.

Segalen, Victor. Essay on Exoticism: An Aesthetics of Diversity. Duke UP, 2002. 